НАУКОВЕ ЖИТТЯ

DOI https: / / doi.org/10.32837/yuv.v0i3.966

\author{
Л. Чулінда, \\ кандидат юридичних наук, доцент, \\ доцент кафедри конституційного, адміністративного \\ та міжнародного права \\ Київського інституту інтелектуальної власності та права \\ Національного університету «Одеська юридична академія»
}

\title{
КРУГЛИЙ СТІЛ НА ТЕМУ «КОНСТИТУЦІЯ ТА КОНСТИТУЦІЙНІ ЦІННОСТІ»
}

21 червня 2019 р. у Київському інституті інтелектуальної власності та права Національного університету «Одеська юридична академія» в м. Києві відбувся круглий стіл, присвячений 23-й річниці Конституції України, на тему: «Конституція та конституційні цінності», організований кафедрою конституційного, адміністративного та міжнародного права.

У круглому столі взяли участь викладачі Київського інституту інтелектуальної власності та права НУ «ОЮА» в м. Києві та Національного технічного університету України «Київський політехнічний інститут ім. Ігоря Сікорського».

Актуальним для обговорення було значення конституційних цінностей як гуманістичних, демократично-правових, універсальних орієнтирів, що мають формалізоване вираження в Конституції України та впливають на конституційне законодавство, конституційну правосвідомість, конституційний правопорядок та публічно-владну практику. Учасники круглого столу звертали увагу на численні виклики, з якими стикаються конституції в сучасному світі, та їхню роль у гарантуванні й охороні конституційних цінностей. Такі виклики часто є спільними для різних держав, адже зумовлені загальними тенденціями конституційного роз- витку в умовах глобалізації і кризових явищ, що охоплюють економічну і соціальну сфери.

3 вітальним словом до учасників круглого столу звернувся директор Київського інституту інтелектуальної власності та права НУ «ОЮА», доктор юридичних наук, Заслужений юрист України В. І. Фелик, який зазначив, що круглий стіл об’єднав фахівців із різних галузей права і став своєрідним форумом для обміну знаннями й інформацією про конституційно-правові проблеми, що виникають у сучасній державі, а також наголосив на значенні конституційних цінностей, задекларованих європейських стандартів у сфері верховенства права, прав людини і громадянина. Актуальні питання українського конституціоналізму найповніше виявляються у конституційних правах, свободах та обов'язках людини і громадянина, в якісно новій організації державної влади, у реалізації чинної Конституції України та у системі іï охорони. Конституціоналізм у доктринальному розумінні $€$ політико-правовою категорією, яка опосередковує місце і роль конституції у правовій системі, суспільстві та державі, іï вплив на процеси демократичної трансформації, проблеми оцінки Конституційним Судом України актів вищих органів державної влади, співвідношення Основ- 


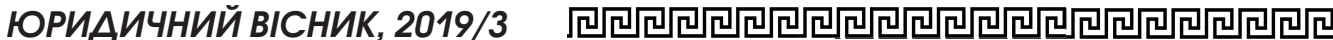

ного Закону та міжнародних договорів України, конституційну реформу судової влади. Перспективи еволюційного розвитку України неможливі без переосмислення конституційних цінностей та формування принципово нових конституційних засад подальшої розбудови демократичної, соціальної, правової держави та гармонійно розвиненого громадянського суспільства в Україні.

Зазначені питання викликали жваві дискусіі та дозволили окреслити подальші напрями конституційного розвитку в Україні.

Доктор юридичних наук, професор, Заслужений юрист України, завідувач кафедри конституційного, адміністративного та міжнародного права А. Р. Крусян зазначила, що цінності сучасного українського конституціоналізму складають певну систему, до якої належать цінності, що визначають: спрямованість (мету) конституціоналізму та зміст його принципів (людина, конституційно-правова свобода, право та верховенство права, демократія тощо), тобто це цінності основоположного характеру; нормативну основу конституціоналізму (конституція як цінність, інтегративне праворозуміння на основі вчень природно-правової, легістської, лібертарно-юридичної аксіологіï); інституціонально-функціональну основу конституціоналізму (публічна влада, зокрема проблема цінності державної та публічно-самоврядної влади, народний суверенітет).

Цінності конституціоналізму мають політико-правову природу. Цей висновок грунтується на тому, що конституціоналізм за своєю суттю є політико-правовим феноменом, а за формою, змістом та функціональним призначенням його можна визначити як публічно-правову систему конституційної організації сучасного суспільства на основі права, демократії та утвердження конституційно-правової свободи людини, яка (ця система) спрямована на обмеження (самообмеження) державної влади на користь громадянського суспільства, прав і свобод людини. Змістом системи конституціоналізму є Конституція, конституційне законодавство, конституційні правовідносини, конституційна правосвідомість та конституційний правопорядок, які також мають політико-правовий вимір.

Основоположне значення у системі цінностей конституціоналізму мають ті 3 них, які визначають мету та зміст принципів сучасного українського конституціоналізму. Тому особливого композиційного значення в системі цінностей конституціоналізму набувають людина та іï конституційно-правова свобода, а також право, верховенство права та демократія як основні цінності сучасного українського конституціоналізму.

Заступник директора Київського інституту інтелектуальної власності та права НУ «ОЮА», доктор юридичних наук, професор, Заслужений юрист України І. П. Голосніченко зосередив увагу присутніх на проблемах децентралізації, яка має відбуватися лише на добровільній основі з урахуванням вимог Конституції України.

Конституція України є основним нормативно-правовим актом, який гарантує добровільне об'єднання територіальних громад. Частина 1 статті 140 Основного Закону України передбачає, що «місцеве самоврядування $€$ правом територіальної громади - жителів села чи добровільного об’єднання у сільську громаду жителів кількох сіл, селища та міста - самостійно вирішувати питання місцевого значення в межах Конституції і законів України». Отже з базових положень Конституції України випливає, що, по-перше, об'єднання територіальних громад має здійснюватися на добровільних засадах; по-друге, територіальні громади мають право самостійно вирішувати питання місцевого значення, тобто без втручання органів державної влади.

Висловлювання деяких політиків про те, що громади в подальшому будуть становити базовий рівень державної влади, який буде мати прямий зв'язок $з$ центральною владою, доповідач 
вважає некоректним. На його думку, подальша організація влади в Україні не зможе обійтися без місцевих органів виконавчої влади. У районах і містах мають функціонувати державні органи для проведення державної політики й управління об’єктами державної власності.

Доктор юридичних наук, професор Національного технічного університету України «Київський політехнічний інститут ім. Ігоря Сікорського» Д .I. Голосніченко зупинився на актуальних проблемах принципів як елемента механізму регулювання повноважень. Принципи у механізмі правового регулювання відіграють вирішальну роль в обгрунтуванні державної політики, яка закріплюється серед іншого шляхом встановлення повноважень. Термін “принцип” походить від латинського principium, що означає - основа, первісність, найголовніші вихідні положення, засоби, що визначають природу i соціальну сутність явища, його спрямованість та найсуттєвіші властивості. Принципи - це об'єктивно-суб'єктивна категорія. Їх об'єктивність полягає в тому, що в них відбиваються об'єктивно діючі закони розвитку суспільства. Ф.Енгельс вважав, що принципи $€$ не вихідним пунктом дослідження, а його прикінцевим результатом, не природа і людство узгоджуються 3 принципами, а навпаки, принципи правильні лише тоді, коли вони відповідають природі та історії.

Однак принципи формулюються людьми, вони існують лише проходячи через людську свідомість. Тому ix можна визначити як основоположні ідеї, які віддзеркалюють дію об'єктивних законів розвитку природи та суспільства і формують зміст процесів, що мають місце в житті, закріплюються в різних ідеологічних формах. Правові принципи залежать від закономірностей відповідного суспільства і держави, в основному закріплені у праві основоположні ідеї, що визначають спрямованість, характер, основи та обсяг правового регулювання суспільних відносин.
Аналізуючи конституційні основи земельного права України доктор юридичних наук, професор В. Д. Сидор відзначила, що земельному праву Україн притаманні особливості, обумовлені специфікою його об'єкта, створеного природою, а не людиною, і предметом - земельними правовідносинами. Унікальність об'єкту і предмету земельного права вимагають конструювання норм земельного права не за загальноприйнятими правовими шаблонами. Вони повинні відображати специфіку землі і земельних ділянок як об'єктів земельних правовідносин. Аналіз конституційних основ земельного права сприятиме розумінню процесу впливу земельних відносин на зміст Конституціï України, а також розкриттю можливостей конституційно-правових норм для регулювання земельних відносин.

Зростання значення охорони земель та їх раціонального й цільового використання обумовлює формування нової характеристики сучасного конституційного ладу. Тому доцільно вже сьогодні визнати земельну основу суспільного (конституційного) ладу як центральну конституційну основу, визначити пріоритет земельних відносин у розвитку суспільства.

Доповідач уважає, що земельні положення Конституції України не повинні розчинятися в нормах соціально-економічного і політичного характеру, підпорядковуватися їм, залежати від них. При цьому значення має не кількість земельних норм, закріплених у Конституції України, а рівень їх правової реалізації і придатність для розвитку в земельному законодавстві. Під земельною основою конституційного ладу розуміється система конституційних положень, що регулюють земельні відносини і відображають мету, функціï та обов'язки держави щодо забезпечення земельних прав і дотримання обов'язків всіма суб'єктами земельних відносин. Вона повинна розглядатися поряд з економічною, політичною, соціальною та іншими основами конституційного ладу України. 


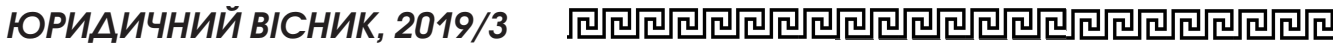

Підтримуючи виступи учасників круглого столу, доктор історичних наук, професор Н. О. Щербак звернула увагу на те, що Українська держава сьогодні переживає непрості часи. В умовах зовнішньої агресії зі сторони Росії Україна мусить водночас вирішувати складні питання реформування найважливіших сфер суспільного життя.

Однією з найбільш актуальних продовжує залишатися проблема реформування судової влади в Україні. Адже людство на всіх етапах розвитку мріяло про справедливий і неупереджений суд. У той же час, як переконує досвід, без реформування судової сфери неможливо впроваджувати й інші важливі реформи в українському суспільстві.

Проводячи реформи в суспільстві, дуже важливо враховувати уроки минулого, передусім власного. Реформування у середині XIX ст., яке хоч i проходило украй суперечливо, але, сприяючи загальній лібералізації суспільних відносин та капіталістичній модернізації тогочасної Росіі, до складу якої входила переважна більшість українських земель, змушував владу змінювати і підходи до внутрішньої політики. Однією зі складових реформаторського курсу імператора Олександра II стала судова реформа 1864 року, яка започаткувала процес трансформації судового відомства відповідно до викликів часу. Реформа суду стала однією з найпослідовніших та найпрогресивніших серед буржуазних реформ 60-70-х років XIX ст. Серед іi основних здобутків: незалежність судової влади від виконавчої, формальна рівність учасників судового процесу, відкритість судових процесів, участь у них адвокатів і т п.

Кандидат історичних наук, доцент Г. I. Трофанчук акцентував увагу присутніх на втіленні досягнень європейської політико-правової думки у Конституції Пилипа Орлика. Хоча після відродження державної незалежності у 1991 р. Конституція Пилипа Орлика набула статусу пам'ятки української філософської та правової думки, все ж ii велич залишається скромною і мало оціненою нашою «науковою і політичною елітою». Про цей документ вже давно слід говорити як про пам'ятку світової політико-правової думки, яка випередила свій час. Що дає підстави для такого твердження? Слід звернути увагу, перш за все, на те, що в нормах цього правового акта ми знаходимо елементи теорії природного права, а головне - положення вчення про поділ влади в організації державного управління за трьома відомими усім напрямами, які мають функціонувати окремо (законодавчий, виконавчий та судовий).

Конституція Пилипа Орлика була, отже, не просто філософським поглядом науковця-одинака, а величезним нормативним кроком до втілення у цивілізаційний обіг теорії поділу державної влади через юридичний акт, ухвалений установчими зборами представників українського народу.

Українська Конституція випередила час. Вона була прийнята тоді, коли французькі та англійські просвітителі лише тільки приступали до розробки гуманістичних ідей і загальногромадянських принципів. Вона увібрала в себе творчі і наукові здобутки тогочасної політичної і правової думки Європи і з повним правом вважається першою демократичною конституцією світу.

Реальної сили Конституція так і не набула, а тому лишилася в історіï як оригінальна правова пам'ятка, своєрідна юридична платформа «мазепинського руху» i, найголовніше, як один із перших конституційних актів в історії Європи, котрий обгрунтовував можливість існування у середовищі феодальних монархій парламентської демократичної республіки.

Висвітлюючи питання основоположних цінностей та принципів конституційного порядку, кандидат історичних наук, доцент О. І. Маложон наголосила на тому, що конституційні принципи розглядаються як певні універсалії, які забезпечуються засо-

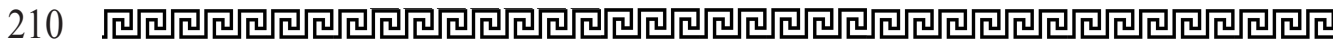


бами правового захисту згідно із конституцією та визначають стандарти та вимоги до законодавства, публічної адміністрації та правосуддя. Про універсалії як морально-політичні засоби легітимації права згадував Імануїл Кант у своїх працях і розглядав їх як основу для досягнення загального миру та формування світового порядку на гуманістичних засадах.

Серед основних рис принципів права привертає увагу те, що принципи $€$ формалізованим вираженням конституційних цінностей як правові універсалії.

Цінності-універсалії забезпечуються через певні інструменти, наприклад, поділ влади чи суверенітет. Конституційні цінності першого порядку (цінності-універсаліі) визначають тип правосвідомості та властиві будь-якій країні із традиціями конституціоналізму і мають характер правових універсалій, що мають надпозитивну природу. Такі принципи діють незалежно від закріплення у позитивному праві, а в разі конституційного закріплення, їній зміст наповнюється через інтерпретацію в доктрині та конституційній юриспруденціі. До основоположних конституційних принципів, які набули універсального характеру, належать: 1) гідність людини; 2) свобода; 3) рівність; 4) справедливість; 5) верховенство права; 6) толерантність.

Кандидат юридичних наук Л. В. Заболотна звернула увагу учасників круглого столу на те, що конституційні цінності інституційного характеру визначають засади конституційного порядку і служать засобами забезпечення цінностей-універсалій. До них належать засади організації публічної влади, критерієм легітимності яких $€$ мистецтво забезпечення публічного інтересу і додержання легітимних підстав для втручання у приватну автономію індивіда.

Легітимність влади передбачає не лише законність, а й офіційне схвалення та сприйняття народом. Адже у демократичних системах частка доз- вільних норм, які грунтуються на ідеях свободи, складає понад 80 \%. Принцип поділу влади охоплює організаційно-правові засади діяльності держави та певні вимоги до ії діяльності. Поділ влади виражається в автономності владних інститутів, гарантій від втручання у їхню діяльність зовні, систему стримувань і противаг.

Верифікація певних принципів досягається через розумність, тобто те, що в англо-американському праві характеризують як розумність і практичну корисність у сенсі ефективного здійснення прав людини. Вимога належної правової процедури часто є чи не вирішальною у визначенні того, чи мало місце свавільне втручання держави у сферу приватної автономії індивіда.

Згідно із засадами розумності положення законів мають бути придатними до застосування і не створювати надмірних обмежень та обтяжень у здійсненні прав і свобод людини, заперечуючи їх сутнісний зміст. Вимоги передбачуваності встановлюють такі стандарти формулювання закону, за яких особа могла планувати та передбачувати наслідки своєї діяльності без надмірних обмежень та обтяжень. Тому й практика застосування закону не має бути надмірно формальною, свавільною та довільною.

Кандидат юридичних наук, доцент Н. С. Панова свій виступ зосередила на проблемі європейського вибору України, демократизації українського суспільства, що зумовлює необхідність створення належної нормативно-правової основи організації та діяльності органів публічного управління, яка повинна бути максимально наближеною до європейських стандартів.

Послідовна й ефективна імплементація Угоди про асоціацію між Україно та ЄC повинна створити міцне підгрунтя для подальшого стійкого політичного й економічного розвитку нашої країни, стати основою стратегіi реформування усіх ключових сфер державного управління і впровадження європейських стандартів з метою підви- 


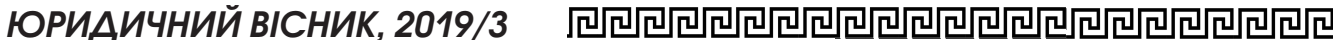

щення якості життя населення. Ефективне державне управління передбачає здатність держави надавати адміністративні послуги і забезпечувати їі економічне зростання і конкурентоспроможність на міжнародній арені.

Державна служба в Україні визнається одним 3 важливих інститутів у справі формування і розвитку державності, від якого залежить функціонування всієї суспільно-політичної системи, вирішення різноманітних завдань і функцій сучасної держави. Державна служба $є$ основою сучасного державного будівництва, здійснює свій вПлив на всі найважливіші конституційно-правові формування. Реформа державної служби значною мірою визначає успіх і інших реформ, результати яких безпосередньо залежать від якості управлінських рішень державних органів.

На думку кандидата юридичних наук, доцента В. К. Рибачека, особлива увага в Конституції України відводиться землі та праву власності на землю. Вона визнається основним національним багатством, що перебуває під особливою охороною держави. При цьому право власності на землю гарантується. Це право набувається i реалізується громадянами, юридичними особами та державою виключно відповідно до закону (стаття $14 \mathrm{KoH}-$ ституції України).

Разом із тим, лише земля з-поміж усіх природних ресурсів визнається основним національним багатством, що перебуває під особливою охороною держави, тоді як на даному етапі розвитку суспільства, внаслідок інтенсивного використання природних ресурсів, конституційна норма повинна бути значно прогресивнішою, зокрема, передбачати особливу охорону державою й інших природних ресурсів, а саме: вод, лісів, надр, тваринного і рослинного світу тощо.

Отже, є підстави резюмувати, що участь у подібних заходах не лише дарує унікальну можливість професійного спілкування з колегами, глибшого розуміння конституційних цінностей, формування реальної, а не уявної конституційно-правової картини світу, а Й дає можливість для переосмислення конституційно-правових проблем України під новим кутом зору, зокрема з позицій глобального підходу. 